УДК 338.2:332.025

\title{
ЕНЕРГОЗБЕРЕЖЕННЯ ТА ЕНЕРГОЕФЕКТИВНІСТЬ ЯК ФАКТОРИ ПІДВИЩЕННЯ КОНКУРЕНТОСПРОМОЖНОСТІ ПІДПРИЕМСТВ ЗАЛІЗНИЧНОГО ТРАНСПОРТУ
}

\author{
Боровик Ю.Т., к.е.н., доцент, \\ Слагін Ю.В., к.е.н., доцент (УкрДУЗТ)
}

У статті розглянуто ефективність впливу таких факторів, як енергозбереження та енергоефективність на підвищення конкурентоспроможності. Запропоновано заходи підвищення ролі иих факторів у системі управління конкурентоспроможністю підприємств залізничного транспорту.

Статтю присвячено питанням упровадження енергозберігаючих заходів у виробництві підприємствзалізничного транспорту, для яких питання енергозбереження $\epsilon$ одним з основних шляхів зниження витрат тапідвищення конкурентоспроможності продукиї. Досліджено сутність енергозбереження та ії вплив на підвищення ефективності виробничої діяльності, визначено шляхи поліпшення використання енергоресурсів.

Ключові слова:конкурентоспроможність підприємств залізничного транспорту, енергоефективність, енергозбереження, ефективні інструменти управління, ефективність виробничої діяльності

\section{ЭНЕРГОСБЕРЕЖЕНИЕ И ЭНЕРГОЭФФЕКТИВНОСТЬ КАК ФАКТОРЫ ПОВЫШЕНИЯ КОНКУРЕНТОСПОБНОСТИ ПРЕДПРЯТИЙ ЖЕЛЕЗНОДОРОЖНОГО ТРАНСПОРТА}

\author{
Боровик Ю.Т., к.э.н., доцент, \\ Елагин Ю.В., к.э.н., доцент (УкрГУЖТ)
}

В статье рассмотрена эффективность влияния таких факторов, как энергосбережение и энергоэффективность на повышение конкурентоспособности. Предложень меры повышения роли этих факторов в системе управления конкурентоспособностью предприятий железнодорожного транспорта.

Статья посвящена вопросам внедрения энергосберегающих мероприятий в производстве предприятий железнодорожного транспорта, для которых вопрос энергосбережения является одним из основных путей снижения затрат и повышения конкурентоспособности продукиии. Исследована сущңность энергосбережения и ее влияние на повышение эффективности производственной деятельности, определень пути улучшения использования энергоресурсов.

Ключевыеслова: конкурентоспособность предприятий жселезнодорожного транспорта, энергоэффективность, энергосбережение, эффективные инструменты управления, эффективность производственной деятельности

(C) Боровик Ю.Т., Слагін Ю.В.
Вісник економіки транспорту і промисловості № 61, 2018 


\title{
ENERGY SAVING AND ENERGY EFFICIENCY AS A FACTOR TO INCREASE COMPETITIVENESS OF RAILWAY TRANSPORT ENTERPRISES
}

\author{
Borovik Y.T., Ph. D., associate Professor, \\ Elagin Y.V., Ph. D., associate Professor (USURT)
}

The article examines the effectiveness of the influence of such factors as energy saving and energy efficiency on increasing competitiveness. Measures to increase the role of these factors in the system of competitiveness management of railway transport enterprises are proposed. The main factor of formation of energy efficiency of industrial enterprises of railway transport is considered, consisting in creation of effectively operating system of management on energy saving.

The article is devoted to the introduction of energy saving measures in the production of railway transport enterprises, for which the issue of energy saving is one of the main ways to reduce costs and increase the competitiveness of products. The essence of energy saving and its influence on increasing the efficiency of production activity are investigated, ways for improving the use of energy resources are determined.

Keywords:competitiveness of railway transport enterprises, energy efficiency, energy saving, effective management tools, efficiency of production activities

Постановка проблеми. Посилення енергетичної кризи, у зв'язку з переходом України до ринкових відносин, призвело до низької ефективності паливоенергетичного комплексу. Даний аспект вплинув на підвищення енергомісткості України, що у 2-4 рази перевищує цей показник у зарубіжних країнах та у світі в цілому. У свою чергу це негативно відбивається на економічному стані країни, що вимагає низки відповідних заходів. У таких умовах найбільш актуальним та ефективним напрямком подолання дефіциту паливноенергетичних ресурсів та підвищення конкурентоспроможності підприємств та країни в цілому становить енергозбереження та енергоефективність. У країні проголошено проведення політики енергозбереження, але далеко не всі механізми та фактори іiі реалізації знаходять своє відображення в існуючому законодавчо-нормативному забезпеченні, що відповідно позначається на їх ефективності.

Необхідність

упровадження пріоритетної політики енергозбереження пов'язана, насамперед, із дефіцитом власних паливно-енергетичних ресурсів, залежністю від країн-експортерів газу i нафти, зростаючою вартістю їх добування, a також iз глобальними екологічними проблемами. Найважливішим завданням сучасних підприємств залізничного транспорту $\epsilon$ економне витрачання енергетичних ресурсів і підвищення ефективності їх використання на всіх стадіях виробництва, тому велика увага приділяється розробленню сучасних технологій і проведенню організаційнотехнічних та економічних заходів щодо підвищення енергоефективності виробництва, а також інвестиціям у розвиток енергозберігаючих технологій, що забезпечують конкурентоспроможність підприємств і створюють надійну основу майбутнього.

Аналіз останніх досліджень і публікацій.Наукові дослідження щодо розробки та реалізації заходів у напрямку енергозбереження проводилися ще на початку XX століття. Основні теоретичні та прикладні розробки, що присвячені проблемам зменшення енергоємності економіки України, забезпечення промисловості енергетичними ресурсами,

Вісник економіки транспорту і промисловості № 61, 2018 
обгрунтуванню рівня енергоефективності належать таким науковцям, як: В.M. Геєць,С.Ф. Єрмілов, Ю.П. Ященко [8], М.А. Вознюк[3], М.Р. Маслікевич, Б.М. Сердюк[11];Р.В. Севастьянов[15]; у т.ч. підвищенню конкурентоспроможності підприємств присвячені праці В.Л. Диканя [4], питанням енергозбереження в транспортному комплексі України Ю.Т.Боровика[2], аспектам ефективності залізничних перевезень і їх значення для економіки - Ю.В. Слагіна[10].

Виділення невирішених раніше частин загальної проблеми.Незважаючи на велику кількість науково-методичні розробок у цій сфері водночас залишаються невирішеними питання визначення впливу енергозбереження та енергоефективності на стан конкурентоспроможності промислових підприємств, зокрема, залізничного транспорту, а також економічні та управлінські аспекти, пов'язані 3 цим економічним явищем, визначення та вдосконалення оптимальних шляхів реалізації енергозберігаючих заходів у виробничій діяльності підприємства.

Формулювання цілей статті (постановка завдання).Головною метою дослідження $\epsilon$ визначення ефективності застосування енергозбереження та енергоефективності в якості факторів підвищення конкурентоспроможності залізничного транспорту, а також зростання їх ролі у системі управління конкурентоспроможністю підприємств залізничного транспорту.

Виклад основного матеріалу дослідження. Фактор енергозбереження $\epsilon$ одним із визначальних для енергетичної стратегії України. В цілому тут фокусуються проблеми як ефективності паливно-енергетичного комплексу, так і здатності останнього у повному обсязі забезпечити ресурсами функціонування національної економіки. Енерговитрати залишаються критично значними в промисловості та житлово-комунальному господарстві, що $\epsilon$ однією із причин низької конкурентоспроможності підприємств й суттєвим бар'єром на шляху їх ефективної інтеграції до світового господарства. Ще однією системною проблемою $є$ низька ефективність використання паливноенергетичних ресурсів.

Сьогодні наукові розробки запроваджуються на загальнодержавному рівні, зокрема державні програми 3 енергозбереження; диференційовані тарифи на електроенергію, що стимулюють енергозбереження; концепції, технічні вимоги та методи вирішення проблем щодо побудови автоматизованих систем обліку енергетичних ресурсів в умовах функціонування світового енергоринку. Енергетичні організації працюють над розробкою i впровадженням нових видів енергії та уникнення проблем сучасної енергетики, а також виробленням заходів із енергозбереження в Україні, реалізація яких неможлива без створення належної нормативної бази.

Законодавчо-нормативні документи України в енергетичній сфері регулюють питання енергозбереження, енергоефективності та встановлюють відповідну компетенцію органів державної влади, наділяючи їх необхідними правами [13]. Окремі документи у сфері енергозбереження безпосередньо стосуються питань зменшення використання енергії, механізмів реалізації заходів із енергозбереження та їх фінансування [5, с. 33]. Хоча нині у сфері енергоефективності діють близько 50 національних стандартів групи «Енергозбереження», проте в Україні не існуе чіткого механізму стимулювання впровадження енергоощадних заходів, немає правил i механізмів їх регулювання, але $\epsilon$ економічне стимулювання енергоефективності. 
Енергетична криза 70-х років минулого століття 3 різким подорожчанням нафти і спадом економіки призвела до усвідомлення необхідності проведення цілеспрямованої державної політики в галузі енергозбереження в багатьох країнах світу. Виникла необхідність у досягненні високих і надійних показників енергопостачання, розробленні заходів щодо скорочення залежності країн-імпортерів від імпортованої нафти, створенні законодавчо-правової бази енергозбереження.

Відповідно законодавству України поняття енергозбереження - це діяльність (організаційна, наукова, практична, інформаційна), яка спрямована на раціональне використання та економне витрачання первинної та перетвореної енергії і природних енергетичних ресурсів у національному господарстві i яка реалізується 3 використанням технічних, економічних та правових методів [1]. Енергоефективність та енергозбереження взаємопов'язані, оскільки енергозбереження $є$ головним фактором підвищення рівня ефективності використання паливно-енергетичних ресурсів. Поняття енергоефективності $\epsilon$ дещо ширшим і містить не лише напрями безпосереднього енергозбереження, а й непрямі, які призводять до зниження споживання паливно-енергетичних ресурсів. Енергоефективність характеризує ступінь використання енергії на одиницю кінцевого продукту.

Енергозберігаюча діяльність на підприємствах залізничного транспорту здійснюється в межах енергозберігаючої політики. Проведення енергозберігаючої політики повинно грунтуватися на результатах економіко-енергетичного обстеження всіх виробничих i невиробничих ланок. Нині основним фактором формування енергоефективності підприємств залізничного транспорту $\epsilon$ створення ефективно діючої системи менеджменту 3 енергозбереження. Ця система повинна мати в собі технічний та організаційно-економічний складники. Технічний складник грунтується на підвищенні ефективності виробництва та зниженні енергоємності продукції за рахунок упровадження заходів 3 енергозбереження, альтернативних джерел енергопостачання, новітніх технологій виробництва, скорочення втрат енергоресурсів, заміщення енергоносіїв. Організаційно-економічний складник грунтується на формуванні на підприємстві служби енергоменеджменту, діяльність якої спрямована на забезпечення раціонального використання паливно-енергетичних ресурсів і базується на отриманні енерготехнологічної інформації за допомогою обліку, на проведенні типового енерготехнологічного вимірювання та перевірки й аналізу ефективності використання паливно-енергетичних ресурсів та впровадженні енергозберігаючих заходів [9, с. 5].

Складники системи менеджменту 3 енергозбереження залежать від міжгалузевих та внутрішньогалузевих зрушень в економіці країни. Згідно 3 Енергетичноюстратегією України на період до 2030 p., прогнозований потенціал енергозбереження країни становитиме в 2030 р. 318,4 млн. т у. п., що майже у півтора рази перевищує наявний рівень споживання первинної енергіï. Впровадження заходів технологічного та структурного енергозабезпечення дасть змогу на 51,3\% зменшити рівень енергоспоживання у 2030 р. - 3621 млн. т у. п. за наявного рівня енергоефективності до 302,7 млн. т у. п. за прогнозованого рівня [6, с. 96].

Менеджмент 3 енергозбереження не слід ототожнювати лише із завданням скорочення витрат енергоресурсів. Його цілі носять більш глобальний характер та визначаються сучасними тенденціями розвитку 
енергозабезпеченням (наданням якісних енергоресурсів за умов їх безперебійного постачання), енергодоступністю (енергоресурси повинні мати ринково обгрунтовану ціну за умов енергоощадливості енергоприйнятністю споживачів), мінімального впливу на екологію).

На мікроекономічному рівні можна виділити такі основні завдання менеджменту 3 енергозбереження [3]: забезпечення зростання рівня ефективності виробництва та розширення обсягу i номенклатури продукції в результаті впровадження енергоефективної техніки та устаткування; визначення, економічна оцінка, розроблення та впровадження енергозберігаючих заходів; створення картини споживання енергоресурсів i проведення аналізу енерговикористання для виявлення потенційних можливостей його економії i, як результат, зниження собівартості готової продукції; зниження негативного впливу процесіввиробництва та використання енергоресурсів на навколишнє природне середовище.

На економічну ефективність продукції залізничної галузі впливають ріст цін на енергоносії, що призводить до збільшення витрат на виробництво, раціональне використання енергоресурсів i використання нетрадиційних i поновлюваних джерел енергії, які сприяють зменшенню витрат на виробництво продукції та кількості платежів за викиди в атмосферу. Це дає змогу зменшити енергоємність, підвищити ефективність залізничних перевезень та їх конкурентоспроможність.

Варто зазначити, що при порівнянні ефективності для суспільства доцільності фінансування розвитку того чи іншого виду пасажирських перевезень слід враховувати не тільки потрібні інвестиції в транспортну інфраструктуру, a i очікувані витрати суспільства. Суспільство отримує довгостроковий економічний ефект інвестуючи у розвиток транспортної інфраструктури пасажирських перевезень с нижчими зовнішніми витратами. Тож залізничні пасажирські перевезення для суспільства більш ефективні за рахунок значно менших зовнішніх витрат залізничного транспорту [10].

Таким чином, бачимо, що такі поняття, як «енергозбереження» i «енергоефективність» є взаємозв'язаними, оскільки здебільшого енергозбереження $\epsilon$ головним чинником підвищення рівня ефективності використання ПЕР. Поняття енергоефективності $\epsilon$ дещо ширшим та містить не лише напрями безпосереднього енергозбереження, а й непрямі заходи, які призводять до зниження споживання паливно-енергетичних ресурсів.

Відповідно до Закону України «Про енергозбереження», енергоефективні продукція, технологія, обладнання - це продукція або метод, засіб iï виробництва, що забезпечують раціональне використання паливно-енергетичних ресурсів порівняно 3 іншими варіантами використання або виробництва продукції однакового споживчого рівня чи 3 аналогічними техніко-економічними показниками [1].

На відміну від енергозбереження, яке, головним чином, спрямоване на зменшення споживання енергії, енергоефективність - це корисна, ефективна витрата енергії. Говорячи про енергоефективність, маємо на увазі не лише енергозбереження, тобто економію енергії у повсякденному житті. Мова йде про раціональне та свідоме використання енергетичних ресурсів, доступних кожному, для їх дбайливого збереження. Для забезпечення енергозбереження на підприємствах залізничного транспорту необхідно впровадити:комплексне застосування економічних стимулів;визначення джерел і напрямів фінансування;створення бази для реалізації економічних заходів, 
використання системи державних стандартів під час визначення розмірів надання економічних пільг і застосування економічних санкцій;уведення платні за нераціональне використання ПЕР; надання юридичним і фізичним особам субсидій, дотацій, податкових, кредитних та інших пільг за стимулювання розробок, упровадження енергозберігаючих технологій, спираючись на існуючу законодавчу й нормативну базу та закордонний досвід [1,5,6,9,12-14,16,17].

Підвищення енергоефективності на підприємствах залізничного транспорту приносить такі результати [11, с. 111]:заощадження коштів, що забезпечує зростання конкурентоспроможності підприємств, особливо у разі зростання цін на енергоносіі; збільшення продуктивності через удосконалення виробничих процесів, що пов'язані зі способом використання енергії; встановлення квот на викиди, що дає змогу знизити залежність від цін на енергоносії, зменшити ризики компанії, що, своєю чергою, підвищує вартість підприємства; скорочення викидів у навколишнє середовище, через що покращується екологічний стан, а 3 ним імідж підприємства.

До основних заходів у сфері енергозбереження на підприємствах залізничного транспорту можна віднести [15, с. 109]: необхідність обліку споживання на найбільш енергоємних ланках виробництва; більш ефективну утилізацію енергї; зниження рівня споживання реактивної потужності зарахунок установлення компенсаційних засобів; підвищення ефективності використанняпалива; використання різноманітних альтернативних видів палива; упровадження автоматичних інструментів моніторингу, управління розподілом та використанням енергоносіїв виробництві; контроль над витратами електричної енергії на освітлення, впровадження

економічних

освітлювальних систем; зниження втрат палива та теплової енергіï за рахунок покращення герметизації термічного обладнання; ремонт теплоізоляції із застосуванням сучасних теплоізоляційних матеріалів; упровадження сучасних систем управління температурними режимами; заміну металевих труб на пластмасові у системах водо-, тепло- та газозабезпечення та ін.

$\begin{array}{ccr}\text { Ступінь } & \text { впливу } & \text { прогресу на } \\ \text { економію } & \text { енергіï } & \text { можливо }\end{array}$ продемонструвати на прикладі парових машин, ККД яких 100 років тому складав 3-5 \%, а зараз досягає - $40 \%$. Застосування ресурсозберігаючих та енергозберігаючих технологій забезпечило значне скорочення споживання палива та матеріалів у розвинутих країнах.

Таким чином, вирішити проблему енергозбереження i підвищення енергетичної ефективності можна тільки комплексно за допомогою: проведення енергообстеження для визначення ефективності енерговикористання i потенціалу енергозбереження; впровадження системи енергетичного менеджменту; розроблення програми заходів із підвищення ефективності енерговикористання, реалізації програми; моніторингу i підтвердження ефекту від реалізованого заходу з енергозбереження.

\section{Висновки i пропозиції.}

Впровадження запропонованих заходів поліпшення стану енергоефективності та енергозбереження, а також дотримання сучасних світових стандартів в енергетичній сфері буде сприяти підприємствам залізничного транспорту досягти високої конкурентоспроможності як на національному, так і міжнародному рівнях.

\begin{tabular}{lcrr}
\multicolumn{2}{c}{ ц цілому } & \multicolumn{2}{c}{ підвищення } \\
енергоефективності & призводить до \\
зниження & витрат & на & енергоносії, \\
підвищення & рентабельності, & зростання
\end{tabular}


конкурентоспроможності підприємств залізничного транспорту. При цьому процес раціонального енергоспоживання доцільно розглядати в межах функціонування системи енергетичного менеджменту підприємства.

\section{ПЕРЕЛІК ВИКОРИСТАНИХ ДЖЕРЕЛ}

1. Закон України «Про енергозбереження» від 16.10.2012 № 5463VI [Електронний ресурс]. - Режим доступу : http://zakon2.rada.gov.ua.

2. Боровик Ю.Т. Основні проблеми та напрямки енергозбереження в транспортному комплексі України / Ю.Т. Боровик // Вісник економіки транспорту і промисловості. -Харків: УкрДАЗТ, 2010. № 30. - С. 16-18.

3. Вознюк М.А. Проблемні аспекти управління процесами енергозбереження на регіональному рівні / М.А. Вознюк // Фінансово-кредитна діяльність: проблеми теорії та практики. - 2013. - Т. 1.- № 14. C. $175-182$.

4. Дикань В.Л. Забезпечення конкурентоспроможності підприємств. Підручник / В.Л.Дикань, Ю.Т.Боровик, О.М. Полякова, Ю.М. Уткіна.- Харків: УкрДАЗТ, 2012. - 415с.

5. Енергетична безпека України: виклики, можливості, сценарії - 2020 [Електронний ресурс]. - Режим доступу : http://aeaep.com.ua/wpcontent/uploads/2013/07/40.pdf.

6.Енергетична стратегія України до 2030 року [Електронний ресурс]. - Режим доступу : http://mpe.kmu.gov.ua/minugol/ doccatalog/document?id=260994.

7. Енергоємність ВВП України лишається у 4 рази вищою за німецьку [Електронний ресурс]. - Режим доступу : http://ua-energy.org/ post/38505.

8. Енергоефективність як ресурс інноваційного розвитку : Національна доповідь про стан та перспективи реалізації державної політики енергоефективності у 2008 році / [Срмілов
С.Ф., Геєць В.М., Ященко Ю.П., Григоровський В.В., Лір В.Е. та ін.]. - К. : HAEP, 2009. - 93 c.

9.Енергозбереження.

Системи енергетичного менеджменту промислових підприємств. Загальні вимоги: ДСТ4472:2008 - К. : Держспоживстандарт України, 2006. - 20 с.

10.Єлагін Ю.В. Реформування і суспільні ефекти пасажирських перевезень залізничної галузі / Ю. В. Єлагін, Н. О. Проценко // Вісник економіки транспорту і промисловості. - 2017. - Вип. 58. - С. 96102.

11. Маслікевич М.Р. Сутність оцінки енергоефективності підприємства / М.Р. Маслікевич, Б.М. Сердюк //Актуальні проблеми економіки та управління.-2011. - Вип. 5. - С. 110-114.

12. Оновлення Енергетичної стратегії України на період до 2030 р. [Електронний ресурс]. - Режим доступу :http://mpe.kmu.gov.ua/fuel/control/ uk/publish/article? artid=222035.

13. Перелік основних нормативноправових актів регулювання питань енергоефективності та енергозбереження [Електронний ресурс]. - Режим доступу : http://mpe.kmu.gov.ua/minugol/control/uk/ doccatalog/list?currDir=208607.

14. Рішення Ради національної безпеки i оборони України «Про стан реалізації державної політики щодо забезпечення ефективного використання паливно-енергетичних ресурсів» [Електронний ресурс]. - Режим доступу : http://zakon2.rada.gov.ua/laws/show/ n0023525-08.

15. Севастьянов Р.В. Проблеми та перспективи енергозбереження на промислових підприємствах / Р.В. Севастьянов // Теоретичні і практичні аспекти економіки та інтелектуальної власності : зб. наук. праць. - Маріуполь : ДВНЗ «ПДТУ», 2013. - Вип. 1. - Т. 2. - С. 107-110.

16. Соціально-економічні механізми стимулювання 
енергозберігаючих заходів на Framework for climate and energy policy регіональному рівні [Електронний ресурс]. [Електронний ресурс]. - Режим доступу : - Режим доступу : https://ec.europa.eu/energy/sites/ener/files/do http://old.niss.gov.ua/monitor/Monitor24/02. cuments/2014_eec_communication_adopted_ htm. 0.pdf.

17. Energy Efficiency and its contribution to energy security and the 2030

\title{
УДК 338.46:641
}

\section{ПРАКТИЧНІ АСПЕКТИ ВИКОРИСТАННЯ ХАРЧОВИХ ВІДХОДІВ НА ПІДПРИЕМСТВАХ ГОТЕЛЬНО-РЕСТОРАННОГО БІЗНЕСУ}

\author{
Бутенко О. П., к.е.н., доцент, \\ Стрельченко Д. О., магістр (ХНУБА)
}

У статті розглянута проблема забруднення навколишнього середовища харчовими відходами. Установлене завдання з необхідності мінімізації зазначених відходів та розроблена їх класифікації з визначенням напрямів одержання додаткового прибутку для підприємств, щзо їх утворюють. Запропоновані практичні кроки реалізації напрямів на прикладі конкретного підприємства, щзо дало змогу визначити рівень майбутніх витрат, зміни, які очікуються та рівень доходу. Установлено, щзо заохочення підприємств готельно-ресторанного бізнесу до ефективного управління гастрономічними відходами є перспективним напрямом не тільки для підприємиів, як можливість отримання додаткового прибутку, а й для країни у иілому через значне зменшення кількості токсичних відходів.

Ключові слова: забруднення навколишнього середовища, утилізація харчових відходів, утворення, складування та можливості вторинного використання харчових відходів для підприємств, сортування сміття, економічне обтрунтування заxодib.

\section{ПРАКТИЧЕСКИЕ АСПЕКТЫ ИСПОЛЬЗОВАНИЯ ПИЩЕВЫХ ОТХОДОВ НА ПРЕДПРИЯТИЯХ ОТЕЛЬНО-РЕСТОРАННОГО БИЗНЕСА}

\author{
Бутенко Е.П., к.э.н, доцент, \\ Стрельченко Д.А., магистр (ХНУСА)
}

В статье рассмотрена проблема загрязнения окружающей среды пищевыми отходами. Установлено задание по необходимости минимизации указанных отходов и разработана их классификация с определением направлений получения дополнительной прибыли для предприятий, которые их образуют. Предложены практические шаги реализации направлений на примере конкретного предприятия, что позволило определить уровень предстоящих расходов, изменения, которые ожидаются и уровень

(С) Бутенко О.П., Стрельченко Д.О.
Вісник економіки транспорту і промисловості № 61, 2018 